\title{
Apoptosis in bovine cumulus-oocyte complexes after exposure to polychlorinated biphenyl mixtures during in vitro maturation
}

\author{
Paola Pocar, Daniela Nestler, Michaela Risch and Bernd Fischer \\ Department of Anatomy and Cell Biology, Martin Luther University Faculty of Medicine, Grosse Steinstrasse 52, \\ D-06097 Halle (Saale), Germany
}

Correspondence should be addressed to P Pocar; Email: paola.pocar@medizin.uni-halle.de

\begin{abstract}
Aroclor-1254 (A-1254) is a commercial mixture of coplanar (dioxin-like) and non-coplanar (non dioxin-like) polychlorinated biphenyls (PCBs) affecting bovine oocyte in vitro maturation (IVM) and developmental competence. In the present study, the role of cumulus cell apoptosis in mediating the toxic effects of PCBs during in vitro maturation has been investigated. Results indicate that exposure of cumulus-oocyte complexes (COCs) to A-1254 significantly induced apoptosis of cumulus cells. Furthermore, A-1254 significantly increased the expression of the pro-apoptotic gene, Bax, concomitantly reducing the level of the anti-apoptotic gene, Bcl-2, in the cumulus cell compartment. The effects of pure mixtures of coplanar (PCB 77, 126 and 169) or non-coplanar (PCB 52, 101 and 153) PCBs were examined. Exposure of COCs to coplanar PCBs affected maturation at doses as low as $\mathbf{1 0 0 . 6} \mathrm{pg} / \mathrm{ml}$. Furthermore, a significant increase in apoptosis and in Bax mRNA expression was observed. No variations in maturation or apoptosis were observed in the non-coplanar PCB group. To further analyze the role of cumulus cells, COCs and denuded oocytes (DOs) have been exposed to A-1254 or coplanar PCBs during IVM. Exposure of COCs significantly reduced the percentage of matured oocytes after $24 \mathrm{~h}$ of culture in both treatments. In contrast, exposure of DOs significantly decreased the maturation rate only at the highest dose investigated (100-fold greater than that affecting COCs). Taken together, the results indicate a direct role of cumulus cell apoptosis in mediating PCB toxicity on bovine oocytes, and a direct relationship between congener planarity and toxicity in bovine oocytes is suggested.

Reproduction (2005) 130 857-868
\end{abstract}

\section{Introduction}

Polychlorinated biphenyls (PCBs) are a structurally related group of halogenated aromatic hydrocarbons that consist of 209 isomers and congeners with different numbers and positions of chlorine atoms substituted on the biphenyl moiety. PCBs have gained widespread industrial applications due to their physical and chemical properties. They were synthesized for approximately 60 years, from the early 1920s until they were banned in many countries during the late 1970s. Because of their chemical stability and extensive industrial use, it became evident in the mid 1960s that PCBs had become ubiquitous and persistent environmental contaminants (Cantlon 1983). To date, it is estimated that $10^{8} \mathrm{~kg}$ PCBs still reside in the biosphere (Boyle et al. 1992) and about 113 different congeners are most frequently detectable in the environment (Crisp et al. 1998). PCBs are small molecules with a low solubility in water but a high solubility in organic solvents, oils and fat
(Ballschmiter et al. 1989). As a result of this lipophilic nature, and their stability and resistance to degradation, PCBs can be found at all levels of the food chain and can accumulate in the animal and human body (Jones 1988, McFarland \& Clarke 1989).

PCBs occur in mixtures of multiple congeners that differ in the numbers and positions of chlorine around the biphenyl ring. It has been reported that different congeners can exert distinct effects (Geisy \& Kannan 1998). PCB congeners without ortho-chlorine substitution have a coplanar structure similar to 2,3,7,8 tetrachlorodibenzo- $p$-dioxin (TCDD) and bind to the arylhydrocarbon receptor (AhR), causing TCDD-like toxicity. However, congeners with ortho-chlorines favor a nonplanar conformation and do not bind to the AhR, eliciting different toxicity from TCDD (Kodavanti \& Tilson 1997).

PCBs exert a variety of toxic effects such as carcinogenicity, immunotoxicity, teratogenicity and reproductive toxicity (Battershill 1994, Safe 1994). Reproductive disorders 
caused by PCBs were first described in the Baltic seal (Reijnders 1986). PCB exposure during pregnancy is reported to cause altered motor function (Pantaleoni et al. 1988) as well as decreased levels of neurotransmitters in the brain (Seegal et al. 1986, 1991). Maternal PCB exposure can lead to pre- and post-implantation embryo loss and reduced survival of the offspring (Ahlborg et al. 1992, Battershill 1994, Seiler et al. 1994). Particularly, PCBs have been reported to decrease implantation rate and litter size in mice and rats (Lindner et al. 1974) and to cause reproductive failure in mink (Platonow \& Karstad 1973). Several reports described the presence of various environmental pollutants, including PCBs, in human follicular fluid (Trapp et al. 1984, Pflieger-Bruss \& Schill 2000) and human ovarian tissue (Mes 1990).

We have recently demonstrated that $\mathrm{PCBs}$ have a severe negative effect on reproductive functions in cattle (Pocar et al. 2001b). An environmentally relevant mixture of over 60 PCB congeners (Aroclor-1254, A-1254) affected oocyte maturation, fertilization and embryo development at doses that ranged between 0.001 and $1 \mu \mathrm{g} / \mathrm{ml}$, the minimum effective dose $(0.001 \mu \mathrm{g} / \mathrm{ml})$ being approximately 10 -fold lower than the mean level found in human follicular fluid in non-exposed women (Trapp et al. 1984). In addition, we observed that, besides a decreased ability of the oocyte to complete the nuclear maturation, a significant impairment of cytoplasmic maturation was observed upon exposure to A-1254 (Pocar et al. 2001 a).

During the process of oocyte development, a close association exists between the oocyte and the surrounding cumulus cells. The cumulus cells form a multilayered mass of cells that surround the oocyte during the maturation process within the follicle. Their function is to protect the developing oocyte and to provide nutrients to it through gap junctions within the cumulus mass and between the latter and the oocyte (Mori et al. 2000, Tatemoto et al. 2000, Fatehi et al. 2002). Cumulus cells are not required for meiosis resumption, but are necessary for both final nuclear and cytoplasmic maturation and can influence the development of the oocyte (Perez \& Tilly 1997, Sun et al. 2001). Due to this close association between oocyte and somatic cells, it is reasonable to hypothesize that cumulus cells may be a target for toxicological injury during oocyte maturation.

One of the ovarian regulative events that may be susceptible to modulation by PCBs is apoptosis. The development of the follicle and its cumulus-oocyte complex (COC) is influenced by various apoptotic mechanisms (Tilly 1996). The spatiotemporal pattern of apoptosis during follicle growth and oocyte maturation is tightly regulated. Disruption of either timing or the magnitude of apoptosis can alter the cell connectivity in the cumulus mass and between cumulus and oocyte, causing deficits in oocyte quality. In fact, the degree of apoptosis has been correlated with the developmental competence of the enclosed oocytes in the bovine (Ikeda et al. 2003).

It has been reported that apoptosis may contribute to PCBinduced toxicity. For example, it was demonstrated that apop- totic cell death induced by 2,2',4,6,6'-pentachlorobiphenyl (PCB 104) or Aroclor-1254 may be one possible mechanism of PCB-mediated immunosuppression of human monocytic cells and murine splenocytes (Yoo et al. 1997, Shin et al. 2000). In addition, results published by Hwang et al. (2001) indicated that 2,2',5,5'-tetrachlorobiphenyl (PCB 52) can induce apoptosis of neuronal SK-N-MC cells in a process that involves down-regulation of Bcl-2 expression. Finally, it has been reported that exposure to $3,3^{\prime}, 4,4^{\prime}$ tetrachlorobiphenyl (PCB 77) and 2,2',4,6,6'-pentachlorobiphenyl (PCB 104) can stimulate apoptotic cell death of endothelial cells (Slim et al. 2000, Lee et al. 2003).

The goals of the study reported herein were threefold: (1) to determine whether the effects of PCBs on bovine oocytes are linked to increased apoptosis in the cumulus cell mass during in vitro maturation, (2) to explore whether congener planarity is relevant for PCB toxicity in bovine oocytes and (3) to investigate the role of cumulus cells on the PCBinduced toxicity previously observed in bovine COCs.

\section{Materials and Methods Polychlorinated biphenyls}

Aroclor-1254 was purchased from Supelco (Bellefonte, PA, USA), dissolved in ethanol (Merck, Darmstadt, Germany) and stored at a final concentration of $100 \mathrm{mg} / \mathrm{ml}$. The stock solution was serially diluted in maturation medium to obtain the desired working concentrations as described in the experimental design, with a maximum content of ethanol in the medium of $0.1 \%(\mathrm{v} / \mathrm{v})$. The same amount of ethanol was present in the control medium.

The PCB congeners employed in the present study were highly purified (99.2 to 99.8 purity according to the supplier's certification after HPLC/DAD and HRGC/MS analysis; Ökometric $\mathrm{GmbH}$, Bayreuth, Germany). Two mixtures of non-ortho-substituted PCB congeners and of ortho-substituted PCB congeners respectively (designated as co-planar and non-coplanar) were selected. The calculated amount of powder was dissolved in DMSO to a final concentration of $3 \mu \mathrm{g}$ total PCBs/ml, in the proportions listed in Table 1. Serial dilutions were freshly made to obtain the desired final concentration as described below.

Table 1 Composition of the PCB mixtures used in the present study.

\begin{tabular}{|c|c|c|}
\hline & IUAPC no. & Weight $(\%)$ \\
\hline \multicolumn{3}{|l|}{ Coplanar PCB mixture } \\
\hline 3,3',4,4'-tetrachlorobiphenyl & 77 & 33.3 \\
\hline $3,3^{\prime}, 4,4^{\prime}$-tetrachlorobiphenyl & 126 & 33.3 \\
\hline $3,3^{\prime}, 4,4^{\prime}, 5,5^{\prime}$-hexachlorobiphenyl & 169 & 33.3 \\
\hline \multicolumn{3}{|l|}{ Non-coplanar PCB mixture } \\
\hline $2,2^{\prime}, 5,5^{\prime}$-tetrachlorobiphenyl & 52 & 60.0 \\
\hline $2,2^{\prime}, 4,5,5^{\prime}$-pentachlorobiphenyl & 101 & 20.0 \\
\hline $2,2^{\prime}, 4,4^{\prime}, 5,5^{\prime}$-hexachlorobiphenyl & 153 & 20.0 \\
\hline
\end{tabular}


Samples with DMSO without PCBs were used as controls (final concentration of DMSO in medium $0.3 \%$ ).

\section{Cumulus-oocyte complexes (COCs) collection}

Ovaries were collected from a local slaughterhouse and transported, within $2 \mathrm{~h}$, to the laboratory in Dulbecco's phosphate balanced saline (PBS), supplemented with $100000 \mathrm{IU}$ penicillin, $100 \mathrm{mg}$ streptomycin and $250 \mu \mathrm{g}$ amphotericin B per liter, maintained at $32-34^{\circ} \mathrm{C}$. All subsequent procedures were conducted at a constant temperature of $36^{\circ} \mathrm{C}$.

COCs were collected from ovarian follicles by slicing with a razor blade in modified Dulbecco's PBS (cat \# D6650) supplemented with $2 \mathrm{IU}$ heparin and $0.1 \%$ BSA Fraction V. Intact COCs were collected in tissue culture medium (TCM) 199 (cat \# M 5017) supplemented with $0.4 \%$ BSA (cat \# A 3156), $25 \mathrm{mM}$ Hepes and $10 \mu \mathrm{g} / \mathrm{ml}$ heparin. COCs were then washed three times in the same medium. Only COCs with at least 3 complete layers of cumulus cells and finely granulated homogeneous ooplasm were selected as suitable for in vitro maturation (IVM) and were used for the following experiments, as previously described (Gandolfi et al. 1997). Cumulus-free oocytes (denuded oocytes, DOs) were obtained by mechanically removing cumulus cells from selected COCs with a narrow-bore pipette.

\section{In vitro maturation}

Basic maturation medium (bMM) was TCM 199, supplemented with $0.68 \mathrm{mM}$ L-glutamine, $25 \mathrm{mMNaHCO}_{3}$, $10 \%(\mathrm{v} / \mathrm{v})$ fetal calf serum, $10 \mathrm{IU} / \mathrm{ml}$ pregnant mare serum gonadotropin (PMSG) and $5 \mathrm{IU} / \mathrm{ml}$ human chorionic gonadotropin (hCG) (Suigonan, Intervet, Wiesbaden, Germany) and $1 \mu \mathrm{g} / \mathrm{ml} 17 \beta$-estradiol. Groups of 25-35 COCs or DOs were matured in $500 \mu \mathrm{l} \mathrm{bMM}$ in four-well dishes (Nunc, Roskilde, Denmark). COCs were incubated for $24 \mathrm{~h}$ at $39^{\circ} \mathrm{C}$ in a humid atmosphere of $5 \% \mathrm{CO}_{2}$ in air.

\section{Evaluation of nuclear maturation}

To assess the rate of meiosis at the end of IVM, a total of 373 oocytes, separated in groups according to the treatment, were analyzed. Oocytes were completely denuded of cumulus cells by repeated pipetting, recovered under a stereomicroscope and transferred onto glass slides in a small drop of fluid. Silicone was used to maintain a coverslip in contact with the oocytes without exerting excessive pressure. The slides were immersed in a 3:1 fixative solution of ethanol/acetic acid for a minimum of $24 \mathrm{~h}$. Nuclear morphology was assessed by staining with $1 \%$ lacmoid and specimens were examined under a phase contrast microscope. Oocytes were classified as: immature (germinal vesicle (GV) and GV breakdown stage), intermediate (metaphase I and anaphase I), and matured (telophase I and metaphase II). Oocytes showing either multipolar meiotic spindle, irregular chromatin clumps or no chromatin were considered as degenerated (Luciano et al. 1999).

\section{Terminal doxynucleotidyl transferase-mediated dUTP nick-end labeling (TUNEL)}

To assess the rate of apoptotic cells, a total of 162 COCs, separated in groups according to the treatment, were analyzed. Briefly, COCs were fixed in 4\% PBS-buffered paraformaldehyde for $20 \mathrm{~min}$ at room temperature. An in situ cell death detection kit using fluorescein-conjugated dUTP and TUNEL (Roche Molecular Biochemicals, Mannheim, Germany) was used for labeling apoptotic cells. COCs were washed three times in PBS- $0.1 \%$ PVA (polyvinyl alcohol) and then permeabilized with 0.5\% Triton X-100 in PBS for $10 \mathrm{~min}$. COCs were washed twice with PBS-0.1\% PVA before labeling. Positive control COCs were treated with $50 \mathrm{U} / \mathrm{ml}$ RNAse-free DNAse in cacodylate buffer for $1 \mathrm{~h}$ at $37^{\circ} \mathrm{C}$ and then washed twice with PBS- $0.1 \%$ PVA prior to labeling. The TUNEL reagent was prepared immediately before use and kept on ice. COCs were placed in $30 \mu \mathrm{l}$ drops of TUNEL reagent and incubated in the dark for $1 \mathrm{~h}$ at $37^{\circ} \mathrm{C}$ in a humidified chamber. The COCs were washed three times with $0.5 \%$ BSA in PBS. Negative controls were performed by omitting the TUNEL reagent. Total cell nuclei were labeled with $10 \mu \mathrm{g} / \mathrm{ml}$ Hoechst in $2.3 \% \mathrm{Na}$-citrate for $5 \mathrm{~min}$ in the dark. After washing twice in PBS-0.1\% PVA, COCs were mounted in Fluoroguard antifade mounting reagent (BioRad, München, Germany). Samples were examined under a Nikon Diaphot microscope equipped with epifluorescence. Apoptosis was determined as the percentage of labeled cells to the total cell number. For each COC, a minimum of 400 cells, divided into four randomly chosen fields of the cumulus mass, was examined.

\section{mRNA isolation and complementary DNA synthesis}

Poly $(A)^{+}$RNA from pooled COCs was extracted using Dynabeads mRNA DIRECT kit (Deutsche Dynal, Hamburg, Germany). Briefly, pools of 3-4 COCs were lysed for $10 \mathrm{~min}$ at room temperature in $200 \mu \mathrm{l}$ lysis buffer $(100 \mathrm{mmol}$ Tris $-\mathrm{HCl}, \mathrm{pH} 8.0,500 \mathrm{mmol} \mathrm{LiCl}, 10 \mathrm{mmol}$ EDTA, $1 \%(\mathrm{w} / \mathrm{v})$ SDS, $5 \mathrm{mmol}$ dithiothreitol). After lysis, $10 \mu \mathrm{l}$ pre-washed Dynabeads oligo $(\mathrm{dT})_{25}$ were pipetted into the tube and binding of poly $(\mathrm{A})^{+}$RNAs to oligo(dT) was allowed for $5 \mathrm{~min}$ at room temperature. The beads were then separated with a Dynal MPC-E magnetic separator, washed twice with $30 \mu \mathrm{l}$ washing buffer A $(10 \mathrm{mmol}$ Tris- $\mathrm{HCl}, \mathrm{pH}$ 8.0, $0.15 \mathrm{mmol} \mathrm{LiCl}, 1 \mathrm{mmol}$ EDTA, $0.1 \%(\mathrm{w} / \mathrm{v})$ SDS) and three times with $30 \mu \mathrm{l}$ washing buffer $\mathrm{B}(10 \mathrm{mmol}$ Tris $-\mathrm{HCl}, \mathrm{pH}$ 8.0, $0.15 \mathrm{mmol} \mathrm{LiCl}$, 1 mmol EDTA). Poly $(A)^{+}$RNAs were then eluted from the beads by incubation in $11 \mu$ l diethyl pyrocarbonate-treated (DEPC) sterile water at $65^{\circ} \mathrm{C}$ for $2 \mathrm{~min}$. Aliquots were immediately used for reverse transcription using the Perkin Elmer (Foster City, CA, USA) PCR Core kit, using $2.5 \mu \mathrm{mol}$ random hexamers to get the widest array of cDNAs. 
RT reaction was carried out in a final volume of $20 \mu \mathrm{l}$ at $25^{\circ} \mathrm{C}$ for $10 \mathrm{~min}, 42^{\circ} \mathrm{C}$ for $1 \mathrm{~h}$, followed by a denaturation step at $99^{\circ} \mathrm{C}$ for $5 \mathrm{~min}$ and immediate cooling on ice.

\section{Oligonucleotide primers for PCR}

Based on the mRNA sequences available at the EMBL databank, the following specific primer pairs were designed: $\beta$-actin (accession number U39357) sense primer: CCAAGGCCAACCGTGAGAAG, antisense primer: CCATCTCCTGCTTCGAAGTCC; Bcl-2 (accession number U92434) sense primer: GAGATGTCCAGTCAGCTGCACC, antisense primer: ATAGGCACCCAGGGTGATGC; Bax (accession number NM173894) sense primer: TGCTTCAGGGTTTCATCCAG, antisense primer: GTGTCCCAAAGTAGGAGAGG. PCR products were sequenced to verify their identity and homology to corresponding mRNA sequences in the EMBL databank.

\section{Semiquantitative PCR}

To normalize signals from different RNA samples, $\beta$-actin transcripts were co-amplified as an internal standard. The amplification reaction was stopped before leaving the exponential phase (29 cycles for $\beta$-actin and 40 cycles for other fragments investigated). Amplifications were performed on $2 \mu \mathrm{l}$ first strand cDNA in a $30 \mu \mathrm{l}$ final volume containing $0.2 \mu \mathrm{M}$ of the primer combinations listed above, $1 \cup$ Taq polymerase (Life Technologies, Karlsruhe, Germany), $0.2 \mathrm{mM}$ dNTPs, $1.5 \mathrm{mM} \mathrm{MgCl}_{2}, 1 \times$ PCR buffer. Amplification cycles comprised a 30 s step at $94^{\circ} \mathrm{C}$ for denaturation, a $30 \mathrm{~s}$ step at $57^{\circ} \mathrm{C}$ for annealing, and a $45 \mathrm{~s}$ step at $72{ }^{\circ} \mathrm{C}$ for elongation. A water control was included to identify possible contamination. In addition, all samples were amplified with an intron-exon spanning primer pair to detect possible genomic DNA contamination.

A volume of $20 \mu \mathrm{l}$ per reaction was subjected to electrophoresis on a $1.5 \%$ agarose gel in Tris-acetate-EDTA (TAE) buffer, containing $0.2 \mu \mathrm{g} / \mathrm{ml}$ ethidium bromide. After separation, the fragments were visualized on a $312 \mathrm{~nm}$ UV-transilluminator. The image of each gel was digitalized using a CCD camera and the intensity of each band was quantified by densitometric analysis using a computerassisted image analysis system (BioProfil, LTF software, LTF Labortechnik, Wasserburg/B, Germany). The relative amount of the mRNA of interest was calculated as a percentage of the intensity of the $\beta$-actin band for the corresponding sample. For each mRNA, experiments were replicated at least three times.

\section{Statistical analysis}

Data for in vitro maturation were analyzed using a binary logistic regression. Controls were assumed as reference group between replicates. Experiments were replicated at least 3 times and each replicate was fitted as a factor. The log likelihood ratio statistic was used to detect between treatment differences using the SPSS statistical package
(SPSS, Chicago, IL, USA). Data for cell number and gene expression were assessed using analysis of variance followed by Duncan's test. Data are presented as mean percentages $( \pm$ S.E.M.) of a minimum of three independent experiments. In all cases the criterion for significance was set at $P<0.05$.

\section{Experimental design}

Experiment 1. Effects of PCBs on the incidence of apoptosis in cumulus cells

Between 25 and 35 COCs per treatment group were cultured for $24 \mathrm{~h}$ in wells containing $500 \mu \mathrm{l}$ bMM or

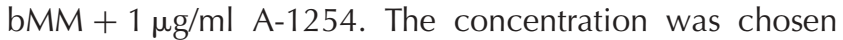
based on previous results showing the concentration able to affect oocyte maturation without inducing unspecific cytotoxicity (Pocar et al. 2001a). After maturation, two groups per treatment (i.e. 3-4 COCs/group) of the matured COCs were snap-frozen in liquid nitrogen and stored for RNA analysis (see above). The remaining COCs (a total of 82 ) were fixed in $4 \%$ paraformaldehyde for the assessment of apoptosis (see above). Experiments were replicated at least 3 times.

\section{Experiment 2.Congener-related effects of PCBs during oocyte maturation}

The effects of either coplanar or non-coplanar PCB mixtures on the nuclear maturation of bovine oocytes were evaluated. Two concentrations of PCBs (100.6 and 201.2 pg/ml coplanar PCBs and 84 and $168 \mathrm{ng} / \mathrm{ml}$ noncoplanar PCBs respectively) were compared with vehicletreated controls. The chosen concentrations were based on previous results reported by Krogenaes et al. (1998), and are considered to be representative of actual in vivo levels of individual PCB congeners (Pauwels et al. 1999). The nuclear status of the oocytes was examined at $24 \mathrm{~h}$. In addition, the incidence of apoptotic cell death was investigated in a total of 80 COCs.

\section{Experiment 3. Role of cumulus cells on PCB-induced toxicity in bovine COCs}

To determine the role of cumulus cells in mediating PCB toxicity, cumulus-enclosed oocytes (COCs) and cumulusfree oocytes (DOs) were exposed during the maturation period to increasing concentrations of A-1254 (between 1 and $100 \mu \mathrm{g} / \mathrm{ml}$ ) or coplanar PCBs (between 0.1 and $10 \mathrm{ng} / \mathrm{ml}$ ). The nuclear status of the oocytes was examined at $24 \mathrm{~h}$.

\section{Results}

\section{Effects of Aroclor-1254 on the incidence of apoptosis in cumulus cells}

As the quality of cumulus cells has been indicated as a crucial factor influencing the outcome of oocyte maturation 

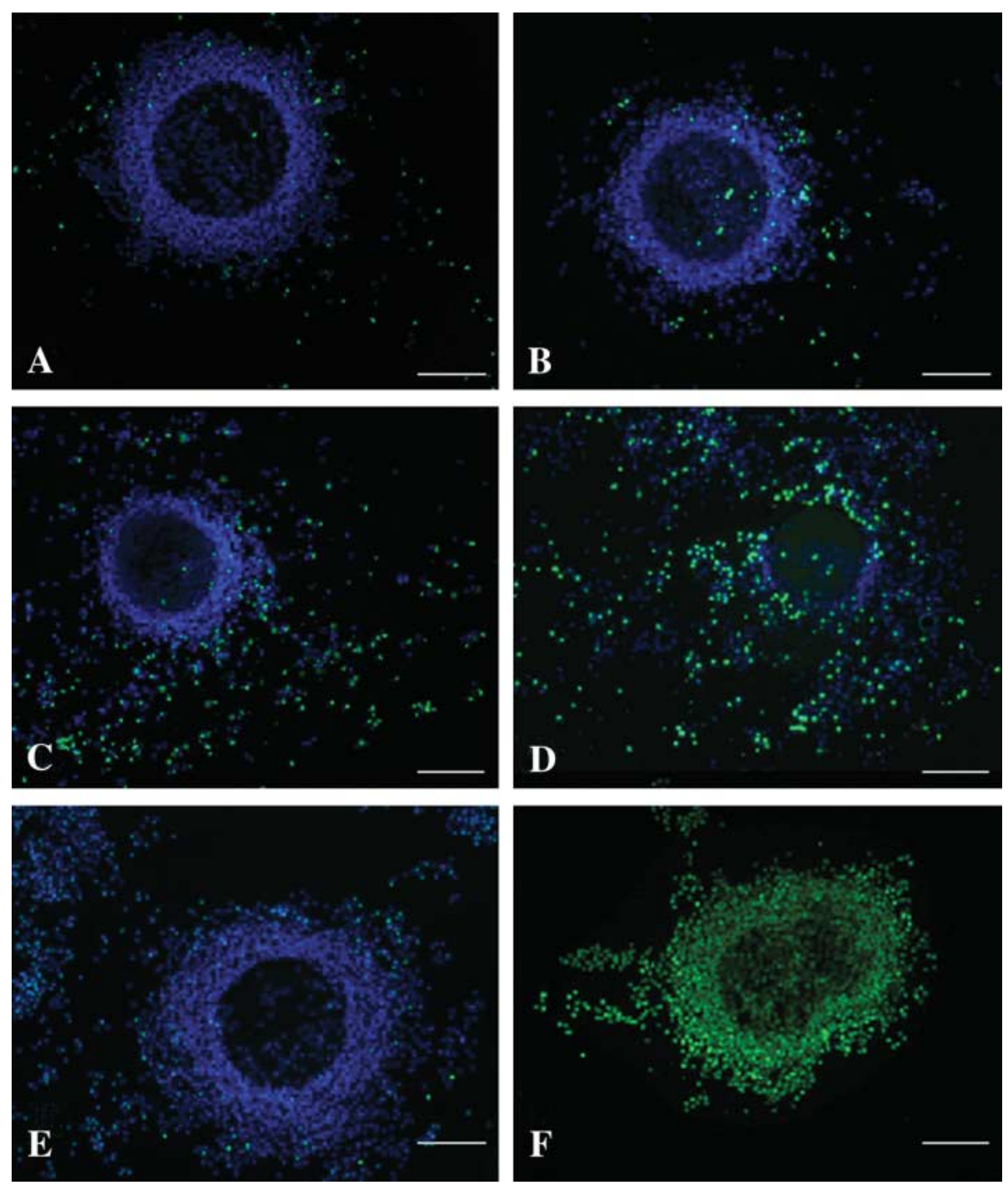

Figure 1 Representative images of bovine cumulus-oocyte complexes after in vitro maturation subjected to TUNEL analysis to determine apoptosis. COCs representing samples from (A) the control group, (B) the DMSO-treated group, (C) the Aroclor-1254-treated group, (D) the coplanar PCB-treated group, (E) the non-coplanar PCB-treated group, and (F) a positive control for TUNEL analysis are shown. Green staining indicates fragmented DNA in cells undergoing apoptosis, whereas intact cell nuclei are stained blue. Scale bar represents $50 \mu \mathrm{m}$. and subsequent developmental competence, the incidence of apoptosis in cumulus cells after exposure to PCBs has been investigated first. As shown in Figs 1 and 2a, the incidence of apoptosis, demonstrated by TUNEL assay in COCs treated with $1 \mu \mathrm{g} / \mathrm{ml} \mathrm{A-1254}$ was significantly higher compared with controls $(P<0.001)$. The expression of $\mathrm{Bcl}-2$ and Bax mRNA, as anti- and pro-apoptotic genes respectively, was examined in the different groups. Results are depicted in Fig. 2b. In accordance with the results obtained by TUNEL, a significant increase in Bax expression was observed in A-1254-treated COCs compared with controls $(P<0.05)$. In A-1254-treated COCs, a significant down-regulation of $\mathrm{Bcl}-2$ gene was observed $(P<0.05)$.

\section{Toxic effects of PCB on bovine COCs are congener specific}

Aroclor-1254 is a highly complex mixture of coplanar and non-coplanar PCB congeners. Therefore, the effects of two pure mixtures of coplanar (PCB 77, 126 and 169) or noncoplanar (PCB 52, 101, and 153) PCBs on bovine oocyte maturation were examined.

Results are summarized in Table 2. Compared with controls without DMSO, the presence of $0.3 \%$ DMSO in the maturation medium did not affect the rate of degenerated oocytes or the rate of incompletely matured oocytes (any stage prior to metaphase II) (data not shown). Similarly, the percentage of completely matured, incompletely matured and degenerated oocytes did not differ significantly between the control group and the group treated with two different concentrations of non-coplanar PCB mixture. Furthermore, there was no difference in the percentage of immature oocytes between COCs treated with or without coplanar PCB mixtures. However, the maturation rate of COCs at the metaphase II stage was significantly decreased by treatment with coplanar PCBs, at doses as low as $100.6 \mathrm{pg} / \mathrm{ml}$ compared with that of untreated COCs. In parallel, an increased percentage of intermediate and degenerated oocytes was observed. 
(a)

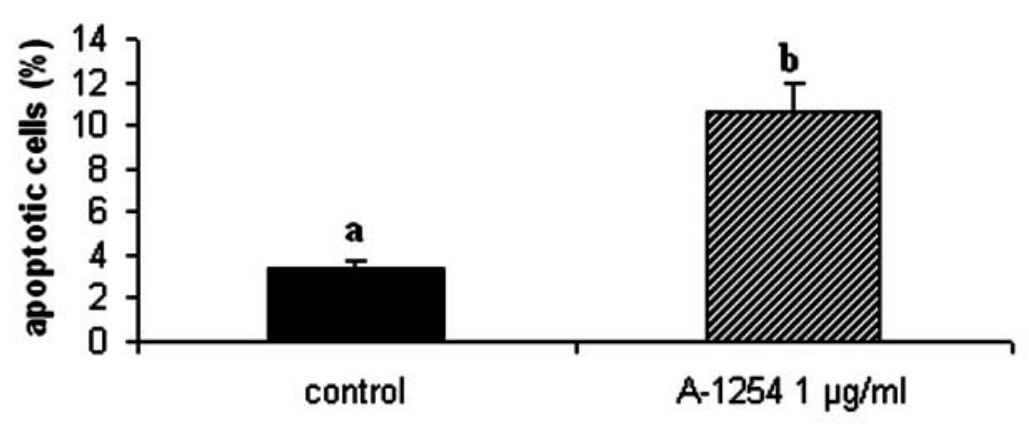

(b)

Bax

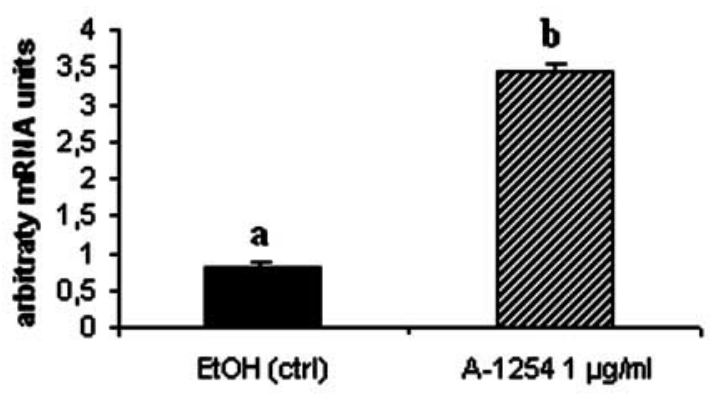

Bel-2

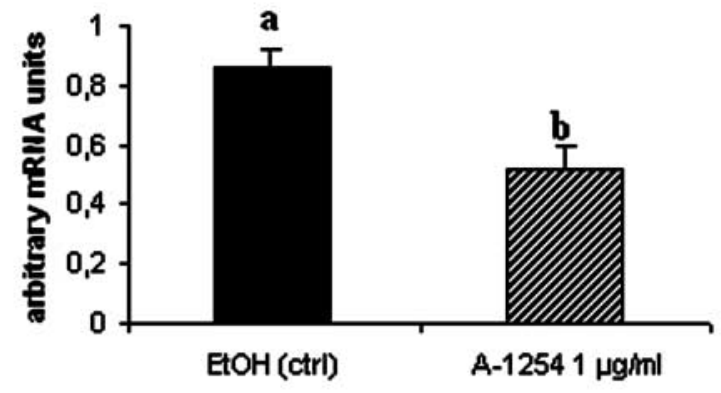

(c)

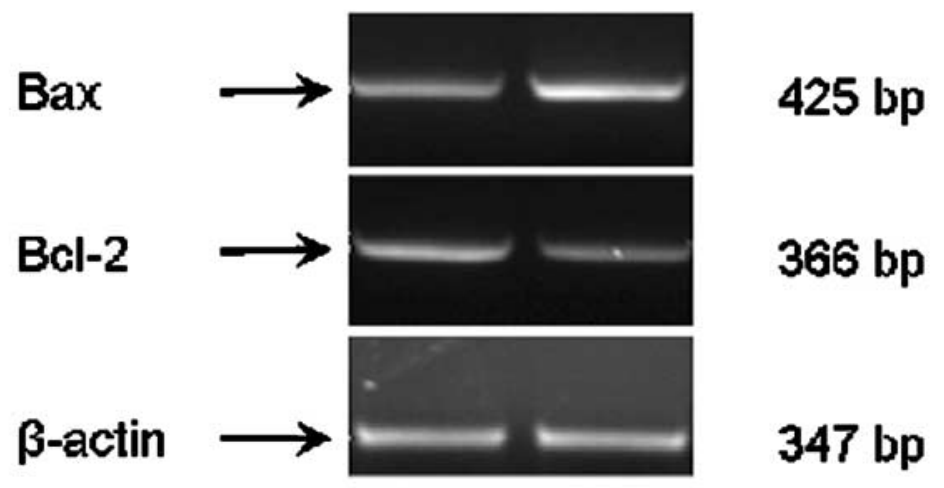

Figure 2 Effects of Aroclor-1254 exposure during in vitro maturation on (a) apoptosis incidence and (b) Bax and Bcl-2 mRNA expression in bovine cumulus-oocyte complexes. The relative amount of the mRNA of interest was calculated as a percentage of the intensity of the $\beta$-actin band for the corresponding sample. The values are expressed as means \pm S.E.M. Values with different superscripts are significantly different $(P<0.05)$. (c) Representative gels of independent experiments. 
Table 2 Effects of coplanar or non-coplanar PCB mixtures on in vitro maturation of bovine oocytes.

\begin{tabular}{|c|c|c|c|c|c|}
\hline Treatment & No. of COCs* & Immature $* *(\%)$ & Intermediate $* *(\%)$ & Mature** $(\%)$ & Degenerate $* *(\%)$ \\
\hline Control & 82 & 2.27 & $17.04^{\mathrm{a}}$ & $80.68^{\mathrm{a}}$ & $0.00^{\mathrm{a}}$ \\
\hline Copl PCB $100.6 \mathrm{pg} / \mathrm{ml}$ & 93 & 2.11 & $32.70^{\mathrm{b}}$ & $59.41^{b}$ & $5.77^{\mathrm{a}, \mathrm{b}}$ \\
\hline Copl PCB $201.2 \mathrm{pg} / \mathrm{ml}$ & 84 & 8.93 & $23.21^{\mathrm{a}, \mathrm{b}}$ & $57.14^{\mathrm{b}}$ & $10.71^{\mathrm{b}}$ \\
\hline Non-copl PCB $84 \mathrm{ng} / \mathrm{ml}$ & 88 & 0.00 & $13.64^{\mathrm{a}}$ & $81.82^{\mathrm{a}}$ & $1.79^{\mathrm{a}, \mathrm{b}}$ \\
\hline Non-copl PCB $168 \mathrm{ng} / \mathrm{ml}$ & 78 & 0.00 & $15.48^{\mathrm{a}}$ & $80.95^{\mathrm{a}}$ & $4.54^{\mathrm{a}, \mathrm{b}}$ \\
\hline
\end{tabular}

* Total number of oocytes allocated for each treatment, $n=3$ replicates per treatment.

** Categorical culture data are expressed as mean percentages of oocytes at the germinal vescicle and germinal vescicle breakdown (immature), metaphase I (intermediate), metaphase II (mature) and degenerate stages of the total number of oocytes evaluated.

${ }^{a, b}$ Different superscripts within the same column denote significant differences $(P<0.05)$. Control has been assumed as reference.

Copl, coplanar; non-copl, non-coplanar.

Finally, no significant differences were observed in the presence of non-coplanar PCBs at doses as high as $168 \mathrm{ng} / \mathrm{ml}$ compared with vehicle-treated COCs for any of the parameters observed.

The incidence of apoptosis in cumulus mass in coplanar or non-coplanar PCBs was investigated. As shown in Figs 1 and $3 \mathrm{a}$, a significant increase in apoptotic cells was observed after exposure to $100.6 \mathrm{pg} / \mathrm{ml}$ coplanar PCBs $(P<0.001)$, whereas no difference in the apoptotic rate was observed upon exposure to $84 \mathrm{ng} / \mathrm{ml}$ of a non-coplanar PCB mixture compared with controls. In addition, the expression of $\mathrm{Bcl}-2$ and $\mathrm{Bax}$ mRNA was examined in the different groups. Results are depicted in Fig. 3b. A significant increase in Bax expression was observed in coplanar PCB-treated COCs compared with controls $(P<0.05)$, whereas no differences were observed in $\mathrm{Bcl}-2$ expression level. No variations in mRNA expression of apoptotisrelated genes were observed in non-coplanar PCB-treated COCs.

\section{Role of cumulus cells on PCB-induced toxicity in bovine COCs}

To analyze the role of cumulus cells on the PCB-induced toxicity in bovine oocytes, COCs and DOs were exposed to increasing concentrations of A-1254 (dose range between 1 and $100 \mu \mathrm{g} / \mathrm{ml}$ ) or coplanar PCBs (dose range between 0.1 and $10 \mathrm{ng} / \mathrm{ml}$ ) during IVM. Results are shown in Tables 3 and 4. As expected, the maturation rate of DOs to metaphase II was significantly lower than that of COCs, regardless of the concentration of $\mathrm{PCBs}$ in the maturation medium $(P<0.05)$. In agreement with previous results, a decrease in the percentage of cumulusenclosed oocytes able to reach the metaphase II stage was observed with A-1254 at doses as low as $1 \mu \mathrm{g} / \mathrm{ml}$ compared with controls $(P<0.001)$. In parallel, an increased percentage of degenerated and not fully matured oocytes was observed $(P<0.001)$. In contrast, in the absence of cumulus cells, a decrease in matured oocytes was observed only upon exposure to $100 \mu \mathrm{g} / \mathrm{ml} \mathrm{A}-1254$ $(P<0.001)$. The lower doses were not effective. Similarly, upon exposure of COCs and DOs to increasing concentrations of coplanar PCBs the rate of incompletely matured oocytes increased in a linear manner with PCB concen- trations only in the COCs group $(P<0.001)$ at doses as low as $0.1 \mathrm{ng} / \mathrm{ml}$. An increased percentage of degenerated and not fully matured oocytes was observed $(P<0.001)$. There were no effects of coplanar PCBs on DOs at doses as high as $1 \mathrm{ng} / \mathrm{ml}$, and a decrease in matured oocytes was observed only in groups exposed to $10 \mathrm{ng} / \mathrm{ml}(P<0.001)$.

\section{Discussion}

We previously demonstrated that exposure of bovine cumulus-oocyte complexes during in vitro maturation to a commercial PCB mixture, Aroclor-1254, affects oocyte maturation, fertilization and developmental competence (Pocar et al. 2001b). Exposure to A-1254 during in vitro maturation is able to decrease the percentage of oocytes that can reach the metaphase II stage at concentrations as low as $0.01 \mu \mathrm{g} / \mathrm{ml}$, whereas fertilization and developmental competence is affected at doses as low as $0.001 \mu \mathrm{g} / \mathrm{ml}$. Furthermore, the negative effect of PCB exposure during maturation is not only limited to the ability of the oocytes to reach the metaphase II stage, but also includes embryonic development, as there is a significant decrease in the proportion of cleaved embryos reaching the blastocyst stage. Further, we have shown that PCB toxicity in bovine oocytes is related to a reduced competence of the oocytes to undergo normal cytoplasmic maturation, as indicated by an abnormal migration of cortical granules during maturation and subsequent fertilization and by changes in the polyadenylation pattern of several maternal mRNAs (Pocar et al. 2001a). Because cumulus cells play an important role in the nuclear and cytoplasmic changes associated with oocyte maturation (Larsen \& Wert 1988, Mattioli et al. 1988, Fukui 1990, Chian \& Sirard 1995, Tanghe et al. 2003), in the present study we decided to investigate whether cumulus cells can modulate the adverse reproductive effects of environmental toxicants.

Apoptosis is defined as programmed cell death for homeostasis and is closely involved with most of the reproductive processes, including follicular atresia (Tilly et al. 1991). The COC comprises an intimate relation between a cumulus cell syncytium in conjunction with the oocyte involving large gap junctions. When stimulated with follicle-stimulating hormone, and prior to the lutei- 
(a)

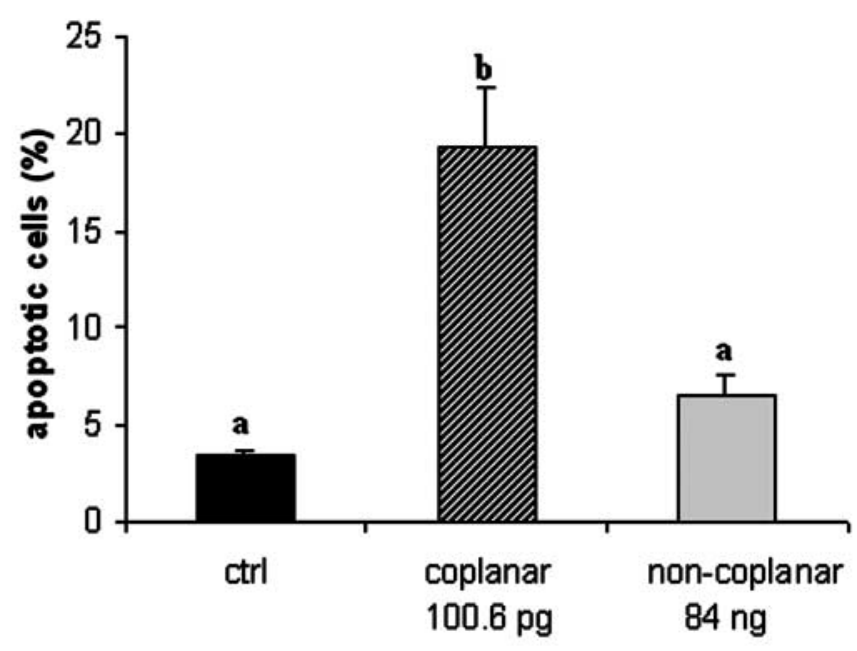

(b)
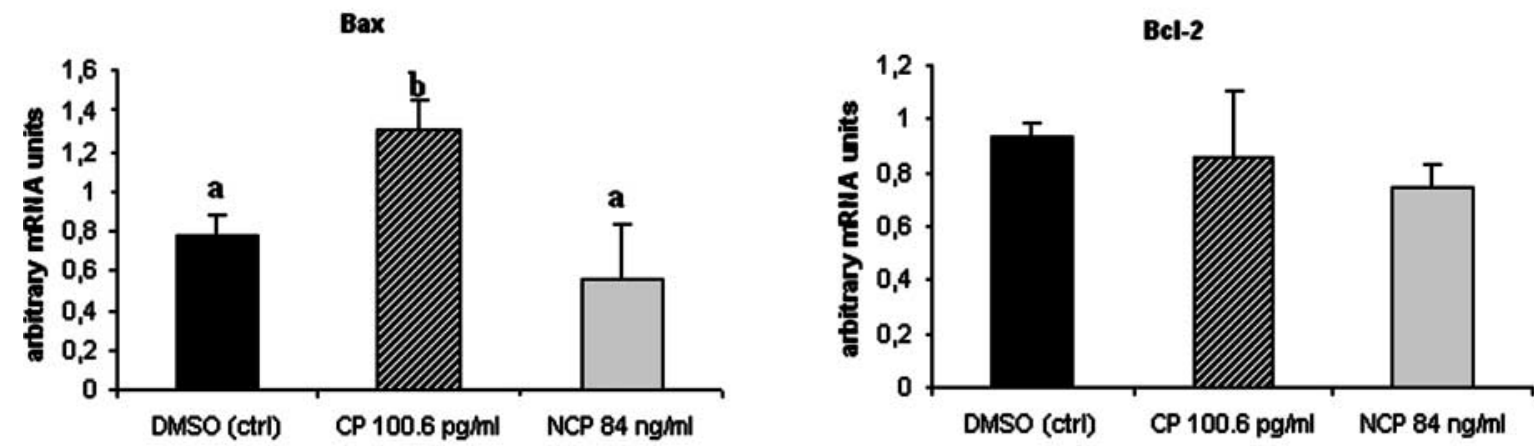

(c)

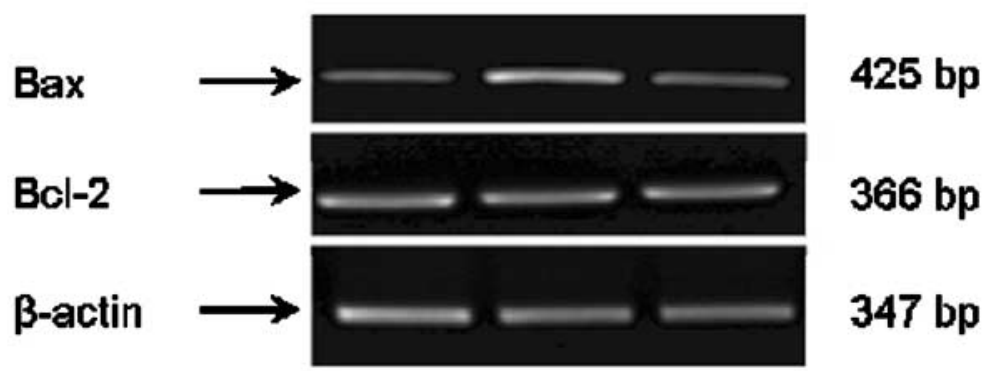

Figure 3 Effects of exposure to PCB mixtures on (a) apoptosis incidence and (b) Bax and Bcl-2 mRNA expression in bovine cumulus-oocyte complexes. The relative amount of the mRNA of interest was calculated as a percentage of the intensity of the $\beta$-actin band for the corresponding sample. The values are expressed as means \pm S.E.M. Values with different superscripts are significantly different $(P<0.05)$. (c) Representative gels of independent experiments. Ctrl, control; CP, coplanar; NCP, non-coplanar. 
Table 3 Effects of cumulus cells on the meiotic progression of bovine oocytes treated with Aroclor (A)-1254.

\begin{tabular}{|c|c|c|c|c|c|}
\hline Treatment & No.* & Immature** $(\%)$ & Intermediate $* *(\%)$ & Mature** (\%) & Degenerate $* *(\%)$ \\
\hline \multicolumn{6}{|c|}{ Cumulus-oocyte complexes } \\
\hline Control & 81 & $1.98^{\mathrm{a}}$ & $13.39^{\mathrm{a}}$ & $82.74^{\mathrm{a}}$ & $1.88^{\mathrm{a}}$ \\
\hline $\mathrm{A}-12541 \mu \mathrm{g} / \mathrm{ml}$ & 69 & $10.53^{\mathrm{a}, \mathrm{b}}$ & $25.57^{\mathrm{b}}$ & $53.99^{b}$ & $9.91^{\mathrm{b}}$ \\
\hline A-1254 $10 \mu \mathrm{g} / \mathrm{ml}$ & 106 & $11.51^{\mathrm{a}, \mathrm{b}}$ & $26.69^{b}$ & $41.37^{\mathrm{C}}$ & $20.43^{\mathrm{c}}$ \\
\hline $\mathrm{A}-1254100 \mu \mathrm{g} / \mathrm{ml}$ & 81 & $20.85^{\mathrm{b}}$ & $23.70^{\mathrm{b}}$ & $40.28^{\mathrm{c}}$ & $15.16^{\mathrm{d}}$ \\
\hline \multicolumn{6}{|l|}{ Denuded oocytes } \\
\hline Control & 75 & 24.86 & 15.96 & $48.77^{\mathrm{a}}$ & $10.41^{\mathrm{a}}$ \\
\hline A-1254 $1 \mu \mathrm{g} / \mathrm{ml}$ & 75 & 36.66 & 13.23 & $45.12^{\mathrm{a}}$ & $4.99^{\mathrm{a}}$ \\
\hline A-1254 $10 \mu \mathrm{g} / \mathrm{ml}$ & 84 & 28.33 & 10.56 & $55.00^{\mathrm{a}}$ & $6.11^{\mathrm{a}}$ \\
\hline A-1254 $100 \mu \mathrm{g} / \mathrm{ml}$ & 78 & 21.83 & 4.31 & $19.94^{\mathrm{b}}$ & $53.90^{\mathrm{b}}$ \\
\hline
\end{tabular}

* Total number of oocytes allocated for each treatment. $n=3$ replicates per treatment.

** Categorical culture data are expressed as mean percentages of oocytes at the germinal vescicle and germinal vescicle breakdown (immature), metaphase I (intermediate), metaphase II (mature) and degenerate stages of the total number of oocytes evaluated.

$a, b, c$ Different superscripts within the same column denote significant differences $(P<0.05)$. Control has been assumed as reference.

nizing hormone peak, these gap junctions are open and allow even large molecules to move freely between the cumulus cells and the oocyte. Signaling molecules for the regulation of the apoptotic process can easily be distributed among cells in the COC. It has been shown that Aroclor-1254 acts as an apoptotic agent in various cell types (Yoo et al. 1997, Perez-Reyes et al. 2001).

The present results clearly demonstrate that exposure to A-1254 during IVM induced apoptotic cell death in cumulus cells, shown by DNA cleavage by TUNEL, the upregulation of the expression level of the pro-apoptotic Bax gene, and the concomitant down-regulation of the level of the anti-apoptotic $\mathrm{Bcl}-2$ gene in treated COCs. These data are in agreement with the results obtained by Campagna and co-workers (2001), demonstrating that exposure to an organochlorine mixture during IVM significantly impaired the quality of cumulus expansion, concomitantly increasing the rate of apoptotic cells of porcine COCs.

We further observed that bovine oocytes cultured without cumulus cells were approximately 100 -fold less susceptible to the effects of A-1254 compared with cumulus-enclosed oocytes, suggesting a direct role of cumulus cells in mediating the toxic effects of A-1254 in bovine oocytes. These data are in agreement with results obtained in the mouse, showing that fertilization of cumulus-free oocytes was not affected by exposure to A-1254 at doses as high as $10 \mu \mathrm{g} / \mathrm{ml}$ (Greenfeld et al. 1998), but fertilization and early embryogenesis of cumulus-enclosed oocytes were significantly reduced (Kholkute et al. 1994).

The results shown in the present study have important practical significance since mixtures of $\mathrm{PCB}$ congeners have been extensively used industrially and now contaminate the environment. The female germ cells are, for asyet poorly understood reasons, extremely vulnerable to environmental biohazards, ultimately causing premature ovarian failure and infertility due to accelerated oocyte depletion (Tilly 2001). However, the mechanism of the toxic effect on the cells and the relevance of apoptotic cell death have not been characterized so far. Because Aroclors are complex mixtures of PCB congeners it is possible that different components are responsible for diverse effects. This possibility was examined in this study using two pure mixtures of PCB congeners.

Only coplanar PCBs affected oocyte maturation and this toxic effect was directly correlated with the presence of cumulus cells, cumulus-free oocytes being approxi-

Table 4 Effects of cumulus cells on the meiotic progression of bovine oocytes treated with a coplanar PCB mixture.

\begin{tabular}{|c|c|c|c|c|c|}
\hline Treatment & No.* & Immature** & Intermediate $* *(\%)$ & Mature** (\%) & Degenerate $^{* *}(\%)$ \\
\hline \multicolumn{6}{|c|}{ Cumulus-oocyte complexes } \\
\hline Control & 81 & 1.98 & $13.39^{\mathrm{a}}$ & $82.74^{\mathrm{a}}$ & $1.88^{\mathrm{a}}$ \\
\hline Copl PCBs $0.1 \mathrm{ng} / \mathrm{ml}$ & 98 & 3.51 & $33.15^{\mathrm{a}, \mathrm{b}}$ & $57.43^{\mathrm{b}}$ & $5.91^{\mathrm{a}, \mathrm{b}}$ \\
\hline Copl PCBs $1 \mathrm{ng} / \mathrm{ml}$ & 90 & 3.03 & $23.53^{\mathrm{b}}$ & $54.04^{\mathrm{b}}$ & $19.39^{\mathrm{b}}$ \\
\hline Copl PCBs $10 \mathrm{ng} / \mathrm{ml}$ & 78 & 0.00 & $50.00^{\mathrm{C}}$ & $38.75^{\mathrm{c}}$ & $11.25^{\mathrm{a}, \mathrm{b}}$ \\
\hline \multicolumn{6}{|l|}{ Denuded oocytes } \\
\hline Control & 75 & 24.86 & 15.96 & $48.77^{\mathrm{a}}$ & $10.41^{\mathrm{a}}$ \\
\hline Copl PCBs $0.1 \mathrm{ng} / \mathrm{ml}$ & 60 & 10.41 & 10.41 & $54.17^{\mathrm{a}}$ & $25.00^{\mathrm{a}}$ \\
\hline Copl PCBs $1 \mathrm{ng} / \mathrm{ml}$ & 72 & 4.17 & 23.21 & $58.93^{\mathrm{a}}$ & $13.69^{\mathrm{a}}$ \\
\hline Copl PCBs $10 \mathrm{ng} / \mathrm{ml}$ & 84 & 3.57 & 24.35 & $27.92^{\mathrm{b}}$ & $44.16^{\mathrm{b}}$ \\
\hline
\end{tabular}

* Total number of oocytes allocated for each treatment. $n=3$ replicates per treatment.

** Categorical culture data are expressed as mean percentages of oocytes at the germinal vescicle and germinal vescicle breakdown (immature), metaphase I (intermediate), metaphase II (mature) and degenerate stages of the total number of oocytes evaluated.

$\mathrm{a}, \mathrm{b}, \mathrm{c}$ Different superscripts within the same column denote significant differences $(P<0.05)$. Control has been assumed as reference.

Copl, coplanar. 
mately 100-fold less sensitive than cumulus-enclosed oocytes. These results are consistent with the experiments of Krogenaes et al. (1998), demonstrating that the coplanar PCB 126 increased the rate of incompletely matured oocytes whereas the non-coplanar congener PCB 153 had no effect, at concentrations similar to those employed in the present study. It is important to notice that the concentration range affecting COCs in the present study is comparable to that observed in the serum of non-exposed women $(0.001$ and $0.4 \mathrm{ng} / \mathrm{g}$ for PCB 126 and 153 respectively; Johansen et al. 1994). Furthermore, Pauwels et al. (1999) showed that a strong correlation exists between serum and follicular fluid PCB content. Our data showed an increase in apoptosis in cumulus cells upon exposure to coplanar compounds while non-coplanar PCBs did not lead to a significant increase in apoptosis compared with controls. A significant increase in the expression level of the proapoptotic gene Bax was observed only upon exposure to coplanar PCBs. These data strongly suggest that the apoptotic cell death of cumulus cells may be a critical factor involved in coplanar PCB toxicity in the bovine oocyte. Krogenaes et al. (1998) previously demonstrated that exposure of bovine cumulus-oocyte complexes during IVM to the non-coplanar PCB 153, although not affecting oocyte maturation significantly, reduced the proportion of oocytes able to undergo the first mitotic divisions. Therefore, the hypothesis that exposure to noncoplanar PCBs during in vitro maturation affects subsequent embryo development through mechanism(s) of action other than apoptosis cannot be ruled out. In addition, in the present study, no differences in the expression level of $\mathrm{Bcl}-2 \mathrm{mRNA}$ in the presence of coplanar PCBs was observed, in contrast to the results obtained upon exposure to A-1254, indicating that a possible interference of non-coplanar PCBs can occur when administered to bovine COCs in complex mixtures with coplanar PCBs. It is therefore possible that subtle changes, not detectable with the presently employed analysis, can occur. Finally, both coplanar and non-coplanar PCBs are able to accumulate in the follicular wall and to alter steroid secretion in follicular cells (Wojtowicz et al. 2000, 2001). Therefore, it is crucial to determine the significance of the present data for PCB toxicity on oocyte maturation in in vivo models, and should be the focus of future research before final conclusions can be drawn.

Coplanar PCBs are structurally related to polychlorinated dibenzofurans and polychlorinated dibenzo-p-dioxins. Many of the biochemical changes and toxic responses elicited by these compounds arise from alterations in gene expression due to interactions with the arylhydrocarbon receptor (AhR), a ligand-transcription factor (Whitlock 1990). Several studies implicate the AhR as having a role in modulating or mediating apoptotic processes. For example, $2,3,7,8$, tetrachlorodibenzo- $p$-dioxin (TCDD) induces apoptosis in normal mice but AhR-deficient mice are not affected (Fernandez-Salguero et al. 1996, Kamath et al. 1997, Zaher et al. 1998). The AhR also modulates aspects of ceramide signaling associated with the induction of apoptosis (Reiners \& Clift 1999). In addition, recently the presence of consensus $A h R$ response elements (XRE) in the promoter region of the pro-apoptotic Bax gene has been demonstrated. That Bax is a transcriptional target for the AhR was confirmed in reporter assays in microinjected mouse oocytes (Matikainen et al. 2002). Furthermore, using the human ovarian xenograft model it was reported that AhR ligands induce Bax expression and apoptosis in human ovarian follicles in vivo (Matikainen et al. 2002). Finally, we recently demonstrated that the AhR is abundantly expressed in bovine oocytes and that its activation is tightly regulated during oocyte maturation (Pocar et al. 2004). The ability of the coplanar PCB mixture used in the present study to activate the AhR signaling pathway was tested in a variety of cell types (Hombach-Klonisch S, personal communication). Based on these data, it is reasonable to hypothesize that the coplanar PCB congeners can induce apoptosis in bovine cumulus-oocyte complexes by a mechanism dependent on AhR receptor activation. Further analyses are in progress to test this hypothesis.

In conclusion, the present study provides evidence that PCB mixtures, at environmentally relevant levels, adversely affect the quality of cumulus cells by inducing apoptosis in a congener-specific manner. Our data point to a specific role of cumulus cells in mediating PCB toxicity during IVM that may account for the reduced maturation and developmental competence of the PCB-treated oocytes.

\section{Funding}

This study was supported by the EU Marie Curie Fellowship Program and by the Wilhelm Roux Program - MLU Halle/Wittenberg. The authors declare that there is no conflict of interest that would prejudice the impartiality of this scientific work.

\section{References}

Ahlborg UG, Brouwer A, Fingerhut MA, Jacobson JL, Jacobson SW, Kennedy SW, Kettrup AA, Koeman JH, Poiger H \& Rappe C et al. 1992 Impact of polychlorinated dibenzo- $p$-dioxins, dibenzofurans, and biphenyls on human and environmental health, with special emphasis on application of the toxic equivalency factor concept. European Journal of Pharmacology 228 179-199.

Ballschmiter K, Rappe C \& Buser HR 1989 Chemical properties, analytical methods and environmental levels of PCBs, PCTs, PCNs and PBBs. In Halogenated biphenyls, terphenyls, naphthalenes, dibenzodioxins and related products, Eds Kimbrough \& Jensen. pp 47-102. Elsevier Science Publishers.

Battershill JM 1994 Review of the safety assessment of polychlorinated biphenyls (PCBs) with particular reference to reproductive toxicity. Human and Experimental Toxicology 13 581-597.

Boyle AW, Silvin C, Tenenbaum SW \& Nakas JP 1992 Aerobic PCB Biodegradation. Biodegradation 3 285-298.

Campagna C, Sirard MA, Ayotte P \& Bailey JL 2001 Impaired maturation, fertilization, and embryonic development of porcine 
oocytes following exposure to an environmentally relevant organochlorine mixture. Biology of Reproduction 65 554-560.

Cantlon JE 1983 The PCB problem: an overview. In PCBs: Human and Environmental Hazards, pp 5-10. Eds EFM D'Itri \& MA Kamrin. Woburn, Massachusetts: Butterworth Publishers.

Chian RC \& Sirard MA 1995 Effects of cumulus cells and follicle-stimulating hormone during in vitro maturation on parthenogenetic activation of bovine oocytes. Molecular Reproduction and Development 42 425-431.

Crisp TM, Clegg ED, Cooper RL, Wood WP, Anderson DG, Baetcke KP, Hoffman JL, Morrow MS, Rodier DJ, Schaeffer JE, Touart LW, Zeeman MG \& Patel YM 1998 Environmental endocrine disruption: An effects assessment analysis. Environmental Health Perspectives 106 Supplement 11-56.

Fatehi AN, Zeinstra EC, Kooij RV, Colenbrander B \& Bevers MM 2002 Effect of cumulus cell removal of in vitro matured bovine oocytes prior to in vitro fertilization on subsequent cleavage rate. Theriogenology 57 1347-1355.

Fernandez-Salguero PM, Hilbert DM, Rudikoff S, Ward JM \& Gonzalez FJ 1996 Aryl-hydrocarbon receptor-deficient mice are resistant to 2,3,7,8-tetrachlorodibenzo- $p$-dioxin-induced toxicity. Toxicology and Applied Pharmacology 140 173-179.

Fukui Y 1990 Effect of follicle cells on the acrosome reaction, fertilization, and developmental competence of bovine oocytes matured in vitro. Molecular Reproduction and Development 26 40-46.

Gandolfi F, Luciano AM, Modina S, Ponzini A, Pocar P, Armstrong DT \& Lauria A 1997 The in vitro developmental competence of bovine oocytes can be related to the morphology of the ovary. Theriogenology 48 1153-1160.

Giesy JP \& Kannan K 1998 Dioxin-like and non-dioxin-like toxic effects of polychlorinated biphenyls (PCBs): implications for risk assessment. Critical Reviews in Toxicology 28 511-569.

Greenfeld CR, Xiongqing W \& Dukelow WR 1998 Aroclor 1254 does not affect the IVF of cumulus-free mouse oocytes. Bulletin of Environmental Contamination and Toxicology $60766-772$.

Hwang SG, Lee HC, Lee DW, Kim YS, Joo WH, Cho YK \& Moon JY 2001 Induction of apoptotic cell death by a p53-independent pathway in neuronal SK-N-MC cells after treatment with 2,2',5,5'-tetrachlorobiphenyl. Toxicology 165 179-188.

Ikeda S, Imai H \& Yamada M 2003 Apoptosis in cumulus cells during in vitro maturation of bovine cumulus-enclosed oocytes. Reproduction 125 369-376.

Johansen HR, Becher G, Polder A \& Skaare JU 1994 Congenerspecific determination of polychlorinated biphenyls and organochlorine pesticides in human milk from Norwegian mothers living in Oslo. Journal of Toxicology and Environmental Health 42 $157-171$.

Jones KC 1988 Determination of polychlorinated biphenyls in human foodstuffs and tissues: suggestions for a selective congener analytical approach. Science of the Total Environment 68 141-159.

Kamath AB, Xu H, Nagarkatti PS \& Nagarkatti M 1997 Evidence for the induction of apoptosis in thymocytes by 2,3,7,8-tetrachlorodibenzo-p-dioxin in vivo. Toxicology and Applied Pharmacology 142 367-377.

Kholkute SD, Rodriguez J \& Dukelow WR 1994 Reproductive toxicity of Aroclor-1254: effects on oocyte, spermatozoa, in vitro fertilization, and embryo development in the mouse. Reproduction and Toxicology 8 487-493.

Kodavanti PR \& Tilson HA 1997 Structure-activity relationships of potentially neurotoxic PCB congeners in the rat. Neurotoxicology 18 425-441.

Krogenaes AK, Nafstad I, Skare JU, Farstad W \& Hafne AL 1998 In vitro reproductive toxicity of polychlorinated biphenyl congeners 153 and 126. Reproduction and Toxicology 12 575-580.

Larsen WJ \& Wert SE 1988 Roles of cell junctions in gametogenesis and in early embryonic development. Tissue Cell 20 809-848.

Lee YW, Park HJ, Son KW, Hennig B, Robertson LW \& Toborek M 2003 2,2' 4, 6,6'-pentachlorobiphenyl (PCB 104) induces apoptosis of human microvascular endothelial cells through the caspase- dependent activation of CREB. Toxicology and Applied Pharmacology $1891-10$.

Lindner RE, Gaines TB \& Kimbrough RD 1974 The effect of polychlorinated biphenyls on rat reproduction. Food Cosmetology and Toxicology 12 63-77.

Luciano AM, Pocar P, Milanesi E, Modina S, Rieger D, Lauria A \& Gandolfi F 1999 Effect of different levels of intracellular cAMP on the in vitro maturation of cattle oocytes and their subsequent development following in vitro fertilization. Molecular Reproduction and Development 54 86-91.

Matikainen TM, Moriyama T, Morita Y, Perez GI, Korsmeyer SJ, Sherr DH \& Tilly JL 2002 Ligand activation of the aromatic hydrocarbon receptor transcription factor drives Bax-dependent apoptosis in developing fetal ovarian germ cells. Endocrinology 143 615-620.

Mattioli M, Galeati G \& Seren E 1988 Effect of follicle somatic cells during pig oocyte maturation on egg penetrability and male pronucleus formation. Gamete Research 20 177-183.

Mes J 1990 PCBs in human populations. In PCBs and the Environment, pp 39-61. Ed. JS Weid. Boca Raton, Florida: CRC Press.

McFarland VA \& Clarke JU 1989 Environmental occurrence, abundance, and potential toxicity of polychlorinated biphenyl congeners: considerations for a congener-specific analysis. Environmental Health Perspectives 81 225-239.

Mori T, Amano T \& Shimizu H 2000 Roles of gap junctional communication of cumulus cells in cytoplasmic maturation of porcine oocytes cultured in vitro. Biology of Reproduction $\mathbf{6 2}$ 913-919.

Pantaleoni GC, Fanini D, Sponta AM, Palumbo G, Giorgi R \& Adams PM 1988 Effects of maternal exposure to polychlorobiphenyls (PCBs) on F1 generation behavior in the rat. Fundamentals of Applied Toxicology 11 440-449.

Pauwels A, Covaci A, Delbeke L, Punjabi U \& Schepens PJ 1999 The relation between levels of selected PCB congeners in human serum and follicular fluid. Chemosphere 39 2433-2441.

Perez GI \& Tilly JL 1997 Cumulus cells are required for the increased apoptotic potential in oocytes of aged mice. Human Reproduction $122781-2783$.

Perez-Reyes PL, Sanchez-Alonso JA, Lopez-Aparicio P, Recio MN \& Perez-Albarsanz MA 2001 Different molecular capacity in the induction of apoptosis by polychlorinated biphenyl congeners in rat renal tubular cell cultures. Bioscience Reproduction 21 765-778.

Pflieger-Bruss S \& Schill WB 2000 Effects of chlorinated hydrocarbons on sperm function in vitro. Andrologia 32 311-315.

Platonow NS \& Karstad LH 1973 Dietary effects of polychlorinated biphenyls on mink. Canadian Journal of Comparative Medicine 37 391-400.

Pocar P, Brevini TAL, Perazzoli F, Cillo F, Modina S \& Gandolfi F 2001 a Cellular and molecular mechanisms mediating the effects of polychlorinated biphenyls on oocyte developmental competence in cattle. Molecular Reproduction and Development 60 535-541.

Pocar P, Perazzoli F, Luciano AM \& Gandolfi F 2001 b In vitro reproductive toxicity of polychlorinated biphenyls: effects on oocyte maturation and developmental competence in cattle. Molecular Reproduction and Development 58 411-416.

Pocar P, Augustin R \& Fischer B 2004 Constitutive expression of CYP1A1 in bovine cumulus oocyte-complexes in vitro: mechanisms and biological implications. Endocrinology 145 1594-1601.

Reijnders PJ 1986 Reproductive failure in common seals feeding on fish from polluted coastal waters. Nature 324 456-457.

Reiners JJ Jr \& Clift RE 1999 Aryl hydrocarbon receptor regulation of ceramide-induced apoptosis in murine hepatoma 1c1c7 cells. A function independent of aryl hydrocarbon receptor nuclear translocator. Journal of Biological Chemistry $2742502-2510$.

Safe SH 1994 Polychlorinated biphenyls (PCBs): environmental impact, biochemical and toxic responses, and implications for risk assessment. Critical Reviews in Toxicology 24 87-149.

Seegal RF, Brosch KO \& Bush B 1986 Polychlorinated biphenyls produce regional alterations of dopamine metabolism in rat brain. Toxicology Letters 30 197-202. 
Seegal RF, Bush B \& Brosch KO 1991 Comparison of effects of Aroclors 1016 and 1260 on non-human primate catecholamine function. Toxicology 66 145-163.

Seiler P, Fischer B, Lindenau A \& Beier HM 1994 Effects of persistent chlorinated hydrocarbons on fertility and embryonic development in the rabbit. Human Reproduction 9 1920-1926.

Shin KJ, Bae SS, Hwang YA, Seo JK, Ryu SH \& Suh PG 2000 $2,2^{\prime}, 4,6,6^{\prime}$-pentachlorobiphenyl induces apoptosis in human monocytic cells. Toxicology and Applied Pharmacology $1691-7$.

Slim R, Toborek M, Robertson LW, Lehmler HJ \& Hennig B 2000 Cellular glutathione status modulates polychlorinated biphenylinduced stress response and apoptosis in vascular endothelial cells. Toxicology and Applied Pharmacology 166 36-42.

Sun QY, Lai L, Bonk A, Prather RS \& Schatten H 2001 Cytoplasmic changes in relation to nuclear maturation and early embryo developmental potential of porcine oocytes: effects of gonadotropins, cumulus cells, follicular size, and protein synthesis inhibition. Molecular Reproduction and Development 59 192-198.

Tanghe S, Van Soom A, Mehrzad J, Maes D, Duchateau L \& de Kruif A 2003 Cumulus contributions during bovine fertilization in vitro. Theriogenology 60 135-149.

Tatemoto H, Sakurai N \& Muto N 2000 Protection of porcine oocytes against apoptotic cell death caused by oxidative stress during in vitro maturation: role of cumulus cells. Biology of Reproduction 63 805-810.

Tilly JL 1996 Apoptosis and ovarian function. Reviews in Reproduction 1 162-172.

Tilly JL 2001 Commuting the death sentence: how oocytes strive to survive. Nature Reviews in Molecular and Cell Biology 2 838-848.
Tilly JL, Kowalski KI, Johnson AL \& Hsueh AJ 1991 Involvement of apoptosis in ovarian follicular atresia and postovulatory regression. Endocrinology 129 2799-2801.

Trapp M, Baukloh V, Bohnet HG \& Heeschen W 1984 Pollutants in human follicular fluid. Fertility and Sterility 42 146-148.

Whitlock JP Jr 1990 Genetic and molecular aspects of 2,3,7,8-tetrachlorodibenzo-p-dioxin action. Annual Reviews in Pharmacology and Toxicology $30251-277$.

Wojtowicz A, Ropstad E \& Gregoraszczuk E 2001 Estrous cycle dependent changes in steroid secretion by pig ovarian cells in vitro to polychlorinated biphenyl (PCB 153). Endocrine Regulations 35 $223-228$.

Yoo BS, Jung KH, Hana SB \& Kim HM 1997 Apoptosis-mediated immunotoxicity of polychlorinated biphenyls (PCBs) in murine splenocytes. Toxicology Letters 91 83-89.

Zaher H, Fernandez-Salguero PM, Letterio J, Sheikh MS, Fornace AJ Jr, Roberts AB \& Gonzalez FJ 1998 The involvement of aryl hydrocarbon receptor in the activation of transforming growth factor-beta and apoptosis. Molecular Pharmacology 54 $313-321$.

Received 18 April 2005

First decision 2 June 2005

Revised manuscript received 3 August 2005

Accepted 16 August 2005 